This item is the archived peer-reviewed author-version of:

Jolted reader

\title{
Reference:
}

Vukovic Vesi.- Jolted reader

Studies in Eastern European cinema - ISSN 2040-350X - (2018)

Full text (Publisher's DOI): https://doi.org/10.1080/2040350X.2018.1446730

To cite this reference: https://hdl.handle.net/10067/1497240151162165141 


\section{Jolted reader}

Jolted Images: Unbound Analytic, Pavle Levi, Amsterdam, Amsterdam University Press, 2017, 216 pp., $€ 29,95$ (paperback), ISBN 978-94-62-98361-8

In the prologue of the book Jolted Images: Unbound Analytic, Pavle Levi describes his childhood memory of being treated for amblyopia (lazy eye) with syntonic therapy, by directing a ray of coloured lights into the eyes. He links this experience with another, diametrically opposite form of eye-light flashing. By emitting rays with piercing gaze, consequentially the environment is changed, such as in the fantasy comics joint artwork by Mirko Ilić and Les Lilley, and by Victor Hussenot. Levi inscribes this active gazing in his own credo 'I look, therefore I jolt the world around me' (16; emphasis original). The importance 'to jolt art, no matter what the outcome' (23), was first underlined by director Dušan Makavejev, after seeing an American modern art exhibition in 1958 in Yugoslavia's capital Belgrade, namely Alexander Calder's kinetic sculptures that encourage tactile experience within the audience. Levi uses Makavejev's stance as a methodological guideline and thus jolts images by becoming an active spectator of someone else's creation. His active gaze does not necessarily change the natural landscape, as in the above-mentioned Hussenot comic, but rather the cinematic landscape by offering a fresh, peculiar and provocative view on renowned, less known and even anonymous image-makers. They utilise different forms of expression: cinema, photography, comic book and poetry. Levi's selection principles, however, remain somewhat unelaborated, considering that the image-makers originate from both European and North American continent, and their styles and means of creation are quite diverse. Levi insists that the images are unified by his approach from multiple perspectives of 'a peculiar sort of viewing, comprehension, and critical interpretation of the image' (21).

Firstly, Levi identifies the oneiric aspect of Roman Polanski's films and his trademark trait - a brief, precise camera movement or movement of object within the shot that mimics camera movement. Levi also delves on the oneiric in 'Ingmar Bergman Dream Film Experiment', which Makavejev undertook in 1978 at Harvard University by editing nineteen dreamlike excerpts without dialogue from Bergman's various films. Furthermore, Levi points out that many of the selected sequences, jolted together in montage, bring to the fore the recurring act of viewing, leading back to the origins in Bergman's dream.

Levi goes on to describe another cinematic experiment, creation by appropriation, conducted by filmmaker Miodrag Milošević in 1983. In the first phase, Milošević shot and reframed the TV broadcast of Last Tango in Paris (Bernardo Bertolucci, 1972) with $8 \mathrm{~mm}$ film camera, thus transforming image from colour into grainy black and white. In the second phase, he projected what he had already filmed, and re-recorded it with $16 \mathrm{~mm}$ film camera. Then, he reedited it, shortened it to twenty minutes and completely amended the soundtrack. Milošević has done all of this in order to venerate his favourite film. Another experimental venture Levi notes is Ivan Martinac's photo-book (1980), resembling a story board, which consisted of still frames generated from The Passion of Joan of Arc (Carl Theodor Dreyer, 1928) enriched with the textual descriptions of those shots. Inspired by Martinac's photo-book, filmmaker Miroslav 
Bata Petrović decided to film it, with the intent to add the original duration of each of Dreyer's shot to the filmed still images. Thus, Levi argues, Martinac, Petrović and Milošević explored the gains and losses in transformations from one media to another.

Furthermore, Levi identifies diverse artists who all have used the motif of a bus. Firstly, Canadian filmmaker and avant-garde artist Michael Snow wrote about it in his text 'First to Last' and also featured a sequence on a bus in his short film Rameau's Nephew by Diderot (Thanx to Dennis Young) by Wilma Schoen (1974). Secondly, Levi draws attention to a photograph of Yugoslav filmmaker Slobodan Šijan, titled Riding the Bus (1973), taken by photographer Juan Carlos Ferro Duque, and a curiosity that Šijan's first feature, now cult film Who is Singing Over There? (1980) mostly takes place on a bus, as if its idea was incepted on the bus from the above-mentioned photograph. Lastly, Levi also finds the motif in a poem $O n$ the bus to Belgrade, written by Yugoslav experimental poet Vujica Rešin Tucić and illustrated by Duško Kirćanski, which is further elaborated in an e-mail correspondence between Levi and director Šijan, thus closing the circle of the bus motif.

Focusing on Želimir Žilnik’s films about the European migrants and people living on the fringes of society, for example the short documentary Inventory (1975) about foreign guest workers in Germany regarded as ethnic others due to their non-German identities, Levi argues that Žilnik's documentaries aim to jolt reality in order to transform it. Žilnik's relentless social criticism is also visible in his more recent work Oldtimer (1988). In this film, as Levi would have it, the intent is to point out to the viewer the staged, thoroughly prepared, orchestrated and funded aspect of political rallies in Yugoslavia, which posed as spontaneous and impromptu. Similar to Žilnik, Bojan Jovanović also addressed the rise of nationalism in the late 1980s in Yugoslavia in Strikes of Clockwork Time (1988). Levi notes that Jovanović investigated the impact of moving images on society with his experimental films, and stressed the omnipresence of TV and movie theatre screens worldwide, which mediate reality.

Levi underlines that he has not and will never watch the film St. George Slays the Dragon (Srđan Dragojević, 2009), since some of the scenes were shot 'within the perimeter of the mining complex that, at the time of the war in Bosnia and Herzegovina, served as a concentration camp for the non-Serb population' (111). Further on,-besides the part of film being shot on its territory, Levi finds it problematic that the Republic of Srpska(where parts of the film were shot), one of Bosnia and Herzegovina's two comprising portions, on which's territory parts of the film were shot, participated in the production. Levi admits that the film's theme does not tackle the wartime events from the bloody Yugoslav wars of secession (19911995) he refers to, but the unrelated World War One (1914-1918) instead. However, Levi uses the fact that Dragojević placed the plot of his film in the distant past, instead of in the recent past which would be to Levi's liking, as a far-fetched argument to reprimand Dragojević because he 'does not at all address but, quite the contrary, erases, marginalizes, or at the very least overlooks, the wartime events in Omarska' (114). Thus, Levi suggests what the film he had not seen should look like thematically.

I question Levi's decision not to view Dragojević's film, as he pointed out due to ethical and political reasons. Levi has not developed such a critical position of boycott consistently 
throughout the book - namely, towards the auteur Polanski about whom he writes in an affirmative manner and does not mention that Polanski has admitted to drugging and raping a 13 year-old girl. Nevertheless, he places Dragojević and his film in the book segment of polysemous title 'Kapo from Omarska'. He punishes them by the gesture of not-watching, even though Dragojević is privately not a war criminal nor sexual assaulter pursued by law. Why does Levi not develop such a critical position towards a self-admitted rapist, paedophile, and fugitive from justice, Polanski, whose whole opus he watched, yet ostracises Dragojević and his film? Is real-life rape not an ethical and political problem as well? It seems Levi's argument ('some films should not be watched'), inspired by Serge Daney, has not been followed through in a methodologically consistent manner in this book. If the author is selective and inconsistent with his critical position to not watch films for political and ethical reasons, he can easily fall into the trap of repressive (self-)censorship, similar to dogmatic cultural watchdogs of socialist Yugoslavia towards Yugoslav New Film in the past, whom Levi himself has criticised in his earlier work Disintegration in Frames: Aesthetics and Ideology in the Yugoslav and PostYugoslav Cinema. In my view, all films should be watched before being subjected to criticism. Just as all books should be read, including Levi's Jolted Images: Unbound Analytic, the polemic potential of which remains uncontested.

My critique does not diminish the book's power to investigate the oneiric: the realm of dreams and nightmares in Bergman's and Polanski's cinema, a bereaved mother's absence of dreams about her two missing children who vanished in the Yugoslav wars, as she searches for their remains in Jasmila Žbanić's short documentary film Red Rubber Boots (2000), and the nightmarish, liminal world between life and death in the Italian comic book Dylan Dog by Tiziano Sclavi. Levi tackles diverse topics and various artists by adding a very personal note to their analyses. Readers will be 'jolted' as Levi induces a dream like state, similar Kharon, the ferryman of Hades, by connecting the living with the undead, and the unconscious with the consciousness of the cinema.

\section{Vesi Vuković}

PhD Candidate at University of Antwerp

University of Antwerp, Stadcampus (De Meerminne), Sint-Jacobstraat 2, M. 371, 2000 Antwerpen, Belgium

vesi.vukovic@uantwerpen.be 